\title{
Does Higher Education Loan Amount affect Students' Class Attendance? Evidence from Privately Sponsored Undergraduate Students in Kenyan Public Universities
}

\author{
Ogenga Paul Akumu ${ }^{1}$
}

\section{ARTICLE INFO}

\section{Article History:}

Received 01.09.2017

Received in revised form

10.10.2017

Accepted

Available online 01.01.2018

\begin{abstract}
This study sought to determine the effect of higher education loan amount awarded to privately sponsored undergraduate students on their frequency of class attendance in Kenyan public universities. The research was conducted with the aid of a representative sample of 517 respondents proportionately drawn from the 2012/2013 cohort of privately sponsored higher education loan recipients in three public universities. Logistic regression analysis was used to model the relationship between loan amount awarded to privately sponsored underg raduate students and their frequency of class attendance while controlling for respondent and university characteristics. The study established that majority of the privately sponsored loan recipients missed classes on weekly basis. However, the findings of the study revealed that higher education loan amount had no signific ant effect on frequency of class attendance. This was attributed to the loan award which was found to be inadequate for sustenance of privately sponsored higher education loan recipients. This study recommends that Higher Education Loans Board should raise the minimum amount of loan awarded to privately sponsored underg raduate students to match with the general cost of private higher education so that they can adequately participate in higher education without much personal sacrifices that would compromise their academics
\end{abstract}

(C) 2018 IJERE. All rights reserved

Keywords:

Higher Education Loan Amount, Frequency of class attendance, Science, Technical, Engineering and Mathematics (STEM)

\section{INTRODUCTION}

Class attendance in higher education is a concept that has been highly debated. Students are usually expected to take accountability and to make choices about attending classes. However, studies show that absenteeism is a significant problem at many institution of higher learning which transcends country, university and discipline in spite of existing state and individual institutional policies (Holdforth, 2007; Leon, 2007; Romer 1993).

Studies have shown that daily absenteeism at the universities can be a s high as one-third to almost onehalf of students in certain disciplines (Friedman, Rodriguez and McComb, 2001; McGuire, 2003; Moore, 2003a; 2003c; 2005). Yet educational practitioners agree that class attendance is an important aspect of student life. This is because it assists student learn differently by bringing theory to life and creating opportunity for discussions, explanation and collaboration on topics.

Moreover, class attendance positively contributes to students' skills in self-management, team work and problem solving. Furthermore, students refine and practice communication and literacy skills with application of numeracy and information technology in class (Braak, n.d). These aspects are crucial in latter students' life and enhance their employability and productivity (Manchester Metropolitan University: Careers \& Employability Service, 2012).

In fact, numerous studies across disciplines have indicated a positive correlation between class attendance and performance. For instance, Thatcher, Fridjhon, and Cockcroft (2007) using second year psychology students established that the students who alw ays attended lectures had a better total mark than those who never or seldom attended.

Similar results have also been posted by studies on students in other disciplines other than psychology. For instance, Crede, Roch, and Kieszczynka (2010) in a Meta analysis showed attendance was strongly related to class exam and GPA levels. Other areas include economics and business (Adair \& Swinton, 2012; Arulampalam, Naylor, \& Smith, 2012; Dobkin, Gil, \& Marion, 2010; Paisley \& Paisley, 2004), engineering (Nyamapfene, 2010), pharmacy (Landin \& Perez, 2015) and health (Cohall \& Skete, 2012).

${ }^{1}$ Corresponding e-mail: pogenga@gmail.com, orcid.org/0000-0002-9250-3400 
Be that as it may, studies show that in the case where students encounter hardship due to insufficient aid as is the case in many developing countries (Nyakunga, 2011; Rugambuka, 2008; Tekleselassie and Johnstone, 2004; Mwinzi, 2002; Nafukho, 2001; Standa, 2000), studies show that they tend to be less engaged in their academics. For instance, in a study entitled "Financial decisions among undergraduate students from low-income and working-class social class backgrounds," Soria, et. al (2014) revealed that whereas universities aspire for students to be fully engaged in academics, low income and working social class background students are more likely to feel stressed by their finances and view college period as time they must work. In contrast, students from upper socio-economic backgrounds tend to be more engaged in campus life (Stuber, 2011). These findings demonstrate the link betw een financial wellbeing of students and their engagement in academic work.

In a related study, Mwinzi (2002) studying the impact of cost-sharing policy on the living conditions of students in Kenyan public universities, show that students who engage in income generating activities as well as study sacrifice part of their study time, since $83.9 \%$ of all income generating activities are operated by students for several hours during the semester. The study further revealed that $55.4 \%$ spent equal to or more than four hours, while $32.3 \%$ used $4-9$ hours, $6.9 \%$ devoted $10-14$ hours while $5.4 \%$ operated their income generating activities betw een 15-18 hours. It is worth noting that regular programmes have classes and other academic activities running between $8.00 \mathrm{am}$ and $7.00 \mathrm{pm}$, this translates to 12 hours of active studies. The study concludes that there is therefore the possibility that academic performance of the students who engage in income generating activities will be negatively affected due to lack of attention to their studies.

\section{Statement of the Problem}

Financial hardship and absenteeism among students have been reported in Keny an pub lic universities. How ever, studies show that financial aid significantly increases student engagement in academic work. It is against this backdrop that the government of Kenya expanded the scope of Higher Education Loans Board (HELB) to cover privately sponsored students in public universities so as to enable the students from lower socio-economic backgrounds to participate in an appropriate form of higher education, without unacceptable deprivation, w ork schedule, or sacrifice (http://w w w.helb.co.ke).This study therefore sought to determine the effect of higher education loan amount on frequency of class attendance by privately sponsored undergraduate students in public universities in Kenya.

\section{METHOD}

\section{Study Sample}

This study was conducted with the aid of a sample of 517 respondents proportionately drawn from the 2012/2013 cohort of privately sponsored higher education loan recipients in three public universities in Kenya. The universities selected were: University of Eldoret (UoE); Jaramogi Oginga Odinga University of Science and Technology (JOOUST); and, Masinde Muliro University of Science and Technology (MMUST). In order to ensure sample representativeness of the entire population, the 2012/2013 cohort of privately sponsored undergraduate higher education loan recipients in the three universities were grouped into three broad strata of STEM, Education, Arts \& Social Sciences, and Economics \& Business related disciplines. Thereafter, the number of respondents from each stratum $w$ as determined using stratified proportionate to size procedure as shown in Table1.

Table 1: Sample of Privately Sponsored HELB Recipients

\begin{tabular}{|c|c|c|c|c|c|c|}
\hline \multirow[t]{2}{*}{ University } & & STEM & $\begin{array}{lr}\text { Education, } & \text { Arts } \\
\text { and } & \text { Social } \\
\text { Sciences } & \end{array}$ & $\begin{array}{l}\text { Economics and } \\
\text { Business }\end{array}$ & \multirow{2}{*}{$\begin{array}{l}\text { Total } \\
\text { Popula } \\
\text { tion }\end{array}$} & \multirow{2}{*}{$\begin{array}{l}\text { Sample } \\
\text { size }\end{array}$} \\
\hline & $\begin{array}{l}\text { Popul } \\
\text { ation }\end{array}$ & Sample & $\begin{array}{l}\text { Popul } \\
\text { ation }\end{array}$ & $\begin{array}{l}\text { Sa } \\
\text { mple }\end{array}$ & & \\
\hline$\overline{\mathrm{UoE}}$ & 202 & 52 & 288 & 222 & 712 & 183 \\
\hline
\end{tabular}




\begin{tabular}{|c|c|c|c|c|c|c|c|c|c|}
\hline JOOUST & 29 & 7 & 119 & & 60 & & 16 & 208 & 54 \\
\hline MMUST & 151 & 39 & 823 & 211 & 117 & & 30 & 1091 & 280 \\
\hline TOTAL & 382 & 98 & 1230 & 316 & 399 & 103 & & 2011 & 517 \\
\hline
\end{tabular}

Source: Population of Privately Sponsored HELB Recipients mapping data, 2015, p. 33

Simple random method was thereafter used to select individual student respondents from among the 2012/2013 cohort of privately sponsored undergraduate higher education loan recipients from the three strata of STEM, Education/Arts/Social Sciences and Business/Economics in the three public universities.

\section{Data Collection Method}

This study used self-completing questionnaire to obtain information on the independent, dependent and control variables from the sampled 2012/2013 cohort of privately sponsored higher education loan recipients. In specific, the students were required to respond to array of questions related to the amount of higher education loan aw arded per year, level of class attendance in the previous semester, type of program of study, socio-economic status, KCSE performance and name of the university. A total of 455 questionnaires were returned out of the 517 administered. This provided a response rate of $88.008 \%$ which was considered adequate for data analysis (Oso and Onen, 2005).

\section{Data Analysis}

Logistic regression analysis was used to fit mean amount of higher education loan against class attendance, while controlling for student-level and university characteristics. Consequently, three sequential regression models were developed. The first model fitted the outcome variable, class attendance against the explanatory variable, mean amount of HELB loan. The second model fitted the outcome variable, class attendance against the explanatory variable, mean amount of higher education loan while controlling for individual student respondent's characteristics. The third model fitted the outcome variable, class attendance against the explanatory variable, mean amount of higher education loan while controlling for both individual student respondent's and university characteristics.

However, prior to modelling, pair-wise correlation and chi-square with Cramer's V were used to correlate the outcome variable (frequency of class attendance) with all possible continuous and categorical explanatory variables respectively with the view of determining which plausible interactions to pursue in the regression models. The null hypothesis was rejected at 5\% if the significance was less than alpha=.05. Only variables which had significant relationship with the dependent variable were pursued further in the regression analysis.

\section{FINDINGS}

\section{Descriptive statistics of higher education loan Amount Award}

The mean, median, mode, range, standard deviation, minimum and maximum amount of higher education loan aw arded to the sampled privately sponsored recipients were established. The findings are presented in Table 2.

Table 2: Descriptive statistics of higher education loan amount

Amount of higher education loan

aw arded per year

Mean

40207.69

Std. Error of

Mean

304.908 


\begin{tabular}{lr} 
Median & 37000 \\
Mode & 35000 \\
Std. & \\
iation & 6503.917 \\
Range & 25000 \\
Minimum & 35000 \\
Maximum & 60000 \\
\hline
\end{tabular}

Data in Table 2 indicate that the students who got the highest amount of higher education loan received Ksh. 60,000, while the ones awarded the least amounts got Ksh. 35,000. However, the mean amount aw arded to privately sponsored undergraduate students in the public universities was Ksh. 40,207.69.

\section{Descriptive statistics of Frequency of Class Attendance}

The privately sponsored higher education loan recipients' level of class attendance in the previous semester was computed and analysed using frequency distribution. Table 3 presents a summary of the findings.

Table 3. Frequency of class attendance

\begin{tabular}{lrcr}
\hline Levels & $\begin{array}{c}\text { Frequ } \\
\text { ency }\end{array}$ & $\begin{array}{c}\text { Perc } \\
\text { ent }\end{array}$ & $\begin{array}{c}\text { Cumulative } \\
\text { Percent }\end{array}$ \\
\hline Never misses lectures & 218 & 47.9 & 47.9 \\
Misses between 1 and 2 lectures on weekly & 235 & 51.6 & 99.6 \\
basis \\
$\begin{array}{l}\text { Misses between 3 and 4 lectures on weekly } \\
\text { basis }\end{array}$ \\
\hline Total
\end{tabular}

Data in Table 3 shows that only $47.9 \%$ of the sampled privately sponsored higher education loan recipients indicated that they never missed classes at the university. The questionnaire item on class attendance required the sampled students to indicate the number of times they miss classes on weekly basis. This is quite alarming since a number of studies across disciplines have indicated a positive correlation between class attendance and performance (Landin \& Perez, 2015; Arulampalam, Naylor, \& Smith, 2012; Adair \& Swinton, 2012; Cohall \& Skete, 2012; Crede, Roch \& Kieszczynka, 2010; Nyamapfene, 2010; Thatcher, Fridjhon, and Cockcroft (2007); Dobkin, Gil, \& Marion, 2010; Paisley \& Paisley, 2004). With such high frequencies of absenteeism, students' academic success could be in jeopardy.

\section{Effect of Higher Education Loan Amount on Frequency of Class Aattendance by Privately Sponsored Undergraduate Students}

The purpose of this study was to determine the effect of higher education loan amount on frequency of class attendance by privately sponsored undergraduate students in public universities in Kenya. The results of the three models of logistic regression are presented in Table 4.

Table 4: Logistic Regression Odds for the Association between Student's Class Attendance and HELB Loans (2012/1 3-

\begin{tabular}{|c|c|c|c|c|}
\hline & & $\begin{array}{l}\text { Model } 1 \\
\text { (a31) }\end{array}$ & Model2 (a31) & Model3 (a31) \\
\hline V ariable & Variable label & $\begin{array}{l}\text { OR } \\
\text { (Std.Err) }\end{array}$ & $\begin{array}{l}\text { OR } \\
\text { (Std.Err) }\end{array}$ & $\begin{array}{l}\text { I OR } \\
\text { (Std.Err) }\end{array}$ \\
\hline a22 & Mean HELB loan allocation 2012/13-2015/16 & 1.0 & 1.00 & 1.00 \\
\hline
\end{tabular}




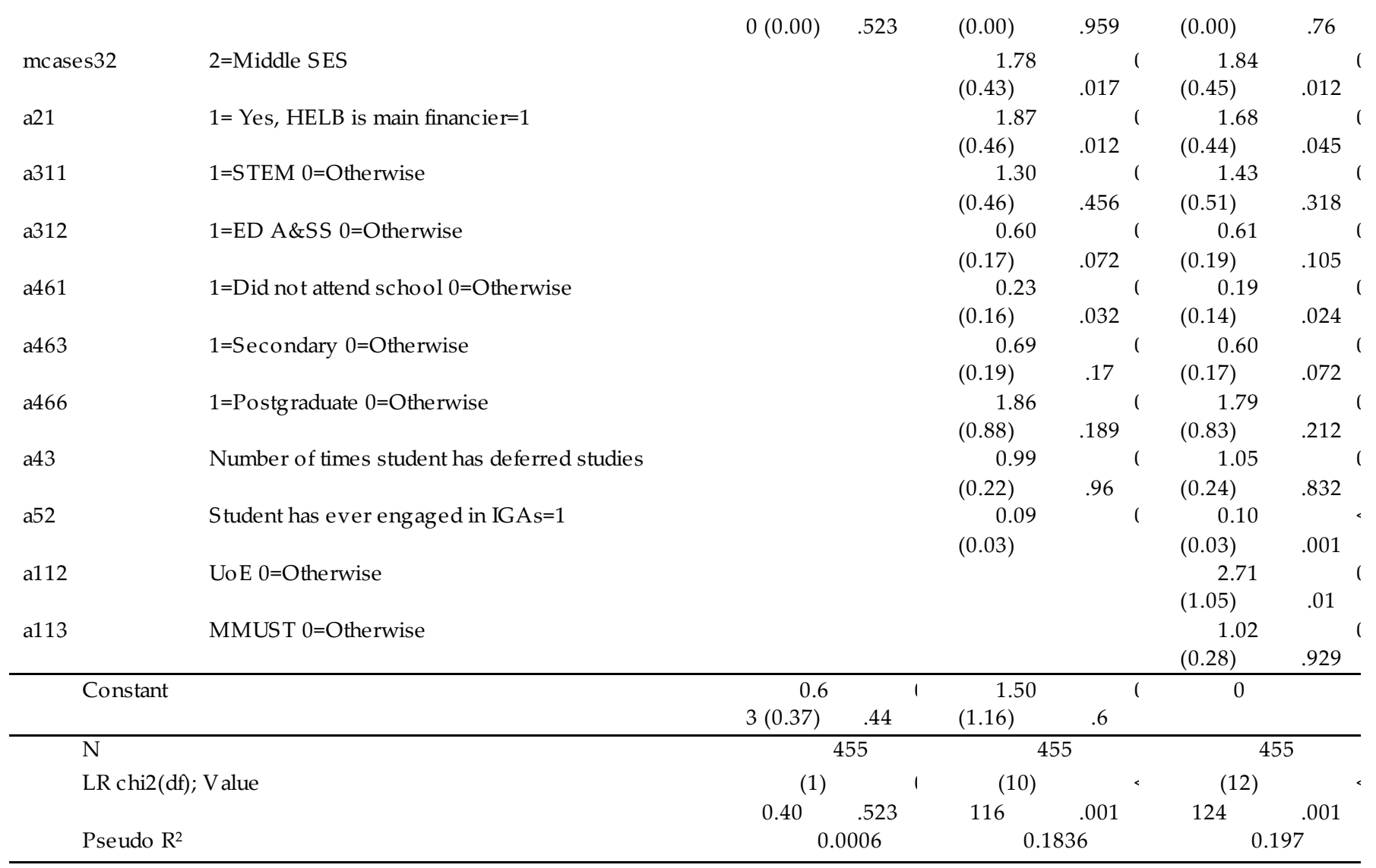

Note. LR=Likelihood Ratio; df=deg rees of freedom; Ays=Academic Years, Source: Stata Output, 2017

In the first model, logical regression was run to determine the effect of the amount of higher education loan (Mean HELB loan allocation 2012/13-2015/16) on class attendance (a41= student never misses classes=1). As shown in Table 4, the study revealed that a one unit increase in mean higher education loan allocation increased the odds of never missed classes by a paltry $0.0006 \%$. Though positive, the increase was negligible. This result was however not statistically significant $(\mathrm{p}=0.523)$. The constants for the model was equally insignificant $(\mathrm{p}=0.440)$ as $\mathrm{w}$ as the overall model $(\mathrm{p}=0.5231)$.

Further, the mean higher education loan allocation still remained statistically insignificant $(p=0.001)$ when student-level characteristics w ere controlled for in the second model when student level characteristics were controlled for. How ever, the overall model was statistically significan $\mathrm{p}<.001 \mathrm{with}$ a pseudo $\mathrm{R}^{2}=0.1836$. The $\mathrm{R}^{2}=0.1836$ implies that the model explained $18.36 \%$ of variations in class attendance of privately sponsored higher education loan recipients in public universities in western Kenya.

In the third model, the Mean higher education loan allocation 2012/13-2015/16 remained statistically insignificant ( $p=0.1970$ with a pseudo $\left.\mathrm{R}^{2}=0.1970\right)$ when both student-level characteristics and university factor were controlled for. However, the overall model was statistically significant $\mathrm{p}<.001$ with a pseudo $\mathrm{R} 2=0.1970$. The $\mathrm{R}^{2}$ of 0.1970 implies that the model explained $19.7 \%$ of variations in class attendance of privately sponsored higher education loan recipients in public universities in western Kenya.

In summary, after the three sequential models, post estimation test of hypothesis for logistic regression was undertaken. See Appendix I. The findings showed likelihood-ratio for class attendance of $\mathrm{chi}^{2}(1)=0.09, \mathrm{p}$ $=0.7600$, which was not statistically significant at alpha 0.05 . The researcher therefore failed to reject the hypothesis.

However, the third model shows that the two student characteristics of socio-economic status and mode of financing higher education remained statistically significant in explaining variations in class attendance by privately sponsored undergraduate higher education loan recipients in public universities in western Kenya. For instance, the model shows that the odds of never missed classes increased by $83.62 \%$ 
$(\mathrm{p}=0.012)$ for students in the middle SES category over other socio-economic status categories. This finding suggests that in spite of higher education loan, socio-economic status has an effect on class attendance by the privately sponsored undergraduate students in the public universities.

\section{DISCUSSION, AND SUGGESTIONS}

The purpose of this study was to determine the effect of higher education loan amount on frequency of class attendance by privately sponsored undergraduate students in public universities in Kenya. The finding suggests that higher education loan amount had no statistically significant effect on class attendance by privately sponsored higher education loan recipients in public universities in western Kenya. The findings of the current study are not inline with those of Hurtado, et. al (2003), which postulated that recipients of student aid worked for significantly fewer hours per week thus allowing them to focus on engagement in college and other aspects of the transition experience.

The reason for variance in the findings of the two studies could be attributed to the fact that Hurtado, et. al (2003) focused on scholarship which covers nearly all direct cost of higher education. The current study how ever looked at higher education loan which did not cover the entire cost of the students' higher education. In fact, the study established that most recipients were only awarded Ksh. 35,000. The mean HELB loan aw ard of Ksh. 40,207.69 was only equivalent to $36.56 \%$ of the cost of tuition per annum for the least expensive category of programmes in Education, Arts and Social Sciences in the public universities. The implication is that the students had to look for other sources of financing to bridge the gap between the amount of loan aw arded and tuition fees charged. These findings point to the fact that HELB loan is indeed an inadequate mode of financing higher education for the majority poor who do not have reliable alternative financing mechanisms.

This is serious since studies show that in the case where students encounter hardship due to insufficient aid as is the case in many developing countries (Nyakunga, 2011; Rugambuka, 2008; Tekleselassie and Johnstone, 2004; Mwinzi, 2002; Nafukho, 2001; Standa, 2000), they tend to be less engaged in their academics. It is no wonder therefore that only $47.9 \%$ of the sampled privately sponsored higher education loan recipients indicated that they never missed classes at the university.

Moreover, an important finding of this study is that socio-economic status still effects class attendance by the privately sponsored undergraduate students in spite of higher education loan. This implies that the higher education loan doesn't promote equal opportunity in education contrary to the expectations of the theoretical paradigm of classical liberal theory. The classical liberal theory states that social mobility will be promoted by equal opportunity of education

The findings of this study are inline with the findings of other previous researches that correlated student's socio-economic status with their engagement in academics activities. One such study is Soria, et. al (2014). In a study entitled "Financial decisions among undergraduate students from low -income and working-class social class backgrounds", Soria, et. al (2014) revealed that low income and working social class background students are more likely to feel stressed by their finances and view college period as time they must work. In contrast, students from upper socio-economic backgrounds tend to be more engaged in academics (Stuber, 2011). This implies that students from low socio-economic status are distracted from focusing on their academics. This may have adverse effects on their academic performance since studies show that class attendance is indeed an important predictor of academic excellence. The studies that have revealed a positive relationship between class attendance and academic performance include: Crede, Roch, \& Kieszczynka (2010), Adair \& Swinton (2012); Arulampalam, Naylor, \& Smith (2012); Dobkin, Gil, \& Marion (2010); Paisley \& Paisley (2004); Nyamapfene (2010); Landin \& Perez (2015), and, Cohall \& Skete (2012)

Consequently, Higher Education Loans Board should raise the minimum amount of loan aw arded to privately sponsored undergraduate students to match with the general cost of private higher education so that the students can adequately participate in higher education without much personal sacrifices that would compromise their academics. 


\section{REFERENCES}

Adair, K., \& Swinton, O. H. (2012). Lab attendance and academic performance. ISRN Educations. http://dx.doi.org/10.5402/2012/364176.

Arulampalam, W., Naylor, R. A., \& Smith, J. (2012). Am I missing something? The effects of absence from class on student performance. Economics of Education Review, 31, 363-375. http://dx.doi.org/10.1016/j.econedurev.2011.12.002

Crede, M., Roch, S. G., \& Kieszczynka, U. M. (2010). Class attendance in college: A meta-analytic view of the relationship of class attendance with grades and student characteristics. American Educational Research Association, 80, 272-295.http://dx.doi.org/10.3102/0034654310362998

Deane, R. P., \& Murphy, D. J. (2013). Student attendance and academic performance in undergraduate obstetrics/gynecology clinical rotations. American Medical Association, 310, 2282-2288. http://dx.doi.org/10.1001/jama.2013.282228

Dobkin, C., Gil, R., \& Marion, J. M. (2010). Skipping class in college and exam performance: Evidence from aregression discontinuity classroom experiment. Economics of Education Review, 29, 566 575.http://dx.doi.org/10.1016/j.econedurev.2009.09.004

Friedman, P., Rodriguez, F and McComb, J (2001). “Why students do and do not attend classes: Myths and realities. College Teaching, 49(4), 124-133.

Healy, M., Carpenter, A. and K. Lynch (1999). Non-completion in higher education: A study of first year students in three institutes of technology. Carlow, Dundalk, Tralee: Institutes of Technology.

Holdforth Joanne Cleary (2007) Student non-attendance in higher education. A phenomenon of student apathy or poor pedagogy. Level3 - June - Issue 5.

Hunter, S., \& Tetley, J. (1999). Lectures - why don't students attend? Why do students attend?, HERDSA Annual International Conference (pp. 1 - 8). Melbourne.

Hurtado S, L. T., and Perorazio, T. (2003). The Transition to College from Low -Income Students: The Impact of Gates Millennium Scholars Program. Centre for the study of higher Education and Post Secondary Education.

Kolari, S., Savander-Ranne, C., \& Viskari, E-L. (2008). Learning needs time and effort: A time-use study of engineering students. European Journal of Engineering Education, 33, 483-498.

Kirby, A., \& McElroy, B. (2003). The effect of attendance on grade for first year economics students in University College Cork. The Economic and Social Review, 34, 311-326.

Launius, M. H. (1997). College student attendance: Attitudes and academic performance. College Student Journal, 31, 86-92. Retrieved from https:/www.questia.com/library/p1917/collegestudent-journal.

Landin, M., \& Perez, J. (2015). Class attendance and academic achievement of pharmacy students in a European University. Currents in Pharmacy Teaching and Learning, 7, 78-83. http://dx.doi.org/10.1016/j.cpt1.2014.09.013.

Launius, M. H. (1997). College student attendance: Attitudes and academic performance. College Student Journal, 31, 86-92. Retrieved from https:/www.questia.com/library/p1917/collegestudent-journal.

Marburger, D. R. (2001). Absenteeism and undergraduate exam performance. The Journal of Economic Education, 32, 99-109.

McGuire, S. (2003) Teaching students how to learn chemistry. Strategies for Success, 4-5. 
Moore, R., Jensen, M., Hatch, J., Duranczyk, I., Staats, S., \& Koch, L. (2003). Showing up: The importance of class attendance for academic success in introductory science courses. American Biology Teacher, 65, 325-329.

Mwinzi, D. (2002). The impact of cost sharing on the living conditions of students in Kenyan Public Universities: The case of Nairobi and Moi Universities. A paper presented the 28thAnnual International Symposium sponsored by the Council for the Development of Social Science Research in Africa (CODESRIA), Dakar and Centres for African Studies University of Illinois, in Dakar, Senegal. 25thto 27th April, 2001.

Nafukho, F.M. (1996), Structural Adjustment Programmes and the Emergence of Entrepreneurial Activities among Moi University Students. Journal of Eastern Africa Research and Development. 26:79-90.

Nyakunga, R.Z (2011) Cost Sharing and Academic Performance. A Case of MZUMBE University: Morogoro Main Campus, Tnazania. Masters Thesis. University of OSLO.

Nyamapfene, A. (2010). Does class attendance still matter? Engineering Education, 5, 64-74.

Otieno, W. (2004). Student Loans in Kenya: Past Experiences, Current Hurdles, and Opportunities for the Future.JHEA/RESA 2(2) 75-99

Oso, W. \& Onen, D. (2005). A General Guide to Writing Research Proposal and Report. Kisumu, Kenya.Options Printers and Publishers .

Paisley, C., \& Paisley, N. J. (2004). Student attendance in an accounting module-reasons for non-attendance and the effect on academic performance at a Scottish University. Accounting Education: An International Journal, 13,39-53. http://dx.doi.org/10.1080/0963928042000310788.

Purcell, P. (2007). Engineering student attendance at lectures: Effect on examination performance. University College Dublin, Ireland. International Conference on Engineering Education - ICEE 2007.

Romer, D. (1993). Do students go to class? Should they? The Journal of Economic Perspectives, 7, 167-174. http://dx.doi.org/10.1257/jep.7.3.167.

Rose, R., Hall, C. W., Bolen, L. M., \& Webster, R. E. (1996). Locus of control and college students' approaches to learning. Psychological Reports, 79, 163-171. http://dx.doi.org/10.2466/pr0.1996.79.1.163

Rugambuka, I. B (2008) The Performance of Higher Education Students' Loan Scheme in Tanzania. The Stakeholders Views. Masters Thesis. University of OSLO

Soria, K. M., Weiner, B., ;\& Lu, E. C. (2014). "Financial Decisions among Undergraduate Students from Low Income and Working-Class Social Class Backgrounds," Journal of Student Financial Aid: Vol. 44: Iss. 1, Article 2. http://publications.nasfaa.org/jsfa/vol44/iss1/2

Standa, E. (2000), Report of the Vice Chancellors' Committee on the Causes of Disturbance Riots in Public Universities Chaired by E. Standa, Jomo Kenyatta Foundation, Nairobi. Nairobi, and Heinemann.

Silvestri, L. (2003). The effect of attendance on undergraduate methods course grades. Education, 123, 483486

Schmulian, A., \& Coetzee, S. (2011). Class absenteeism: Reasons for non-attendance and the effect on academic performance. Accounting Research Journal, 24, 178-194. http://dx.doi.org/10.1108/10309611111163718 
Thatcher, A., Fridjhon, P., \& Cockcroft, K. (2007). The relationship between lecture attendance and academic performance in an ungraduated psychology class. South African Journal of Psychology, 37, 656-660. http://dx.doi.org/10.1177/008124630703700316

Victoria Alexander1 \& Richard Edward Hicks1 ( 2016) Does Class Attendance Predict Academic Performance in First Year Psychology Tutorials? International Journal of Psychological Studies; 8 (1)

Woodfield, R., Jessop, D., \& McMillan, L. (2006). Gender differences in undergraduate attendance rates. Studies in Higher Education, 31,1-22. http://dx.doi.org/10.1080/03075070500340127 